This item was submitted to Loughborough's Research Repository by the author.

Items in Figshare are protected by copyright, with all rights reserved, unless otherwise indicated.

\title{
Anne Venn's a wise virgins lamp burning (1658) in the household of Anne Dunch, sister-in-law to Richard Cromwell
}

PLEASE CITE THE PUBLISHED VERSION

http://dx.doi.org/10.1093/notesj/gjq130

PUBLISHER

(c) Oxford University Press

VERSION

AM (Accepted Manuscript)

LICENCE

CC BY-NC-ND 4.0

\section{REPOSITORY RECORD}

Adcock, Rachel C.. 2019. "Anne Venn's a Wise Virgins Lamp Burning (1658) in the Household of Anne Dunch, Sister-in-law to Richard Cromwell”. figshare. https://hdl.handle.net/2134/14913. 
This item was submitted to Loughborough's Institutional Repository (https://dspace.lboro.ac.uk/) by the author and is made available under the following Creative Commons Licence conditions.

\section{creative
commons}

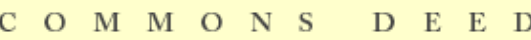

Attribution-NonCommercial-NoDerivs 2.5

You are free:

- to copy, distribute, display, and perform the work

Under the following conditions:

Attribution. You must attribute the work in the manner specified b the author or licensor.

Noncommercial. You may not use this work for commercial purposes.

No Derivative Works. You may not alter, transform, or build upon this work.

- For any reuse or distribution, you must make clear to others the license terms of this work.

- Any of these conditions can be waived if you get permission from the copyright holder.

Your fair use and other rights are in no way affected by the above.

This is a human-readable summary of the Leqal Code (the full license).

\section{Disclaimer 만}

For the full text of this licence, please go to: http://creativecommons.org/licenses/by-nc-nd/2.5/ 


\section{ANNE VENN'S A WISE VIRGINS LAMP BURNING (1658) IN THE HOUSEHOLD OF ANNE DUNCH, SISTER-IN-LAW TO RICHARD CROMWELL}

The signatures of Anne Dunch and her family can be found inscribed on the last page of Anne Venn's book of Puritan spiritual experiences, $\underline{\text { A Wise }}$ Virgins Lamp Burning, now in the possession of the British Library. ${ }^{1}$ Anne Dunch, née Major, was the co-heir, with her sister Dorothy, of Merdon Manor on the Hursley Park estate in Hampshire. After her marriage on 2 July 1650, to John Dunch, Anne stayed there with her sister, newly married to Richard Cromwell who also resided there. On the list of names Anne's appears first, dated 1658, showing she acquired it in the year of its publication. The name of John Dunch, her husband, appears second in a different script, presumably his own, along with their two daughters' names, Anne and Dulcabella, in the same handwriting. Below is the name of Major Dunch, the eldest son and heir, signed, presumably, by himself, and then Samuel Dunch's signature in the style of his father's. ${ }^{2}$ These marks of family ownership reveal the importance of the narrative to Anne and her family, leading us to wonder if it was used in family devotion, and as an example of how different family members (particularly Anne and her daughters) could scrutinize their relationship with God. The signatures also point towards shared religio-political allegiances between the families of Anne Venn and Anne Dunch.

Anne Venn’s spiritual experiences were published in 1658, by her stepfather, Thomas Weld, with the information on the title-page that they were 'written by her own hand, and found in her closet after her death' (A8). Isaac 
Knight, Venn's minister at the gathered church she attended at Fulham, added a preface to these experiences which he describes as follows:

\section{[PROSE EXTRACT]}

She wrote her dayly Meditations upon the holy book of God, which shee kept in a book fair written. She contracted all she heard in the publike Ministry into a method, \& in a book in Folio hath fairly transcribed some part of that work which would have contained the substance of all the labours of the Ministers of Christ, whose Ministry she was partaker of. And in another had written all the attributes of God and Christ that she could finde in Scripture for the strengthening of the faith of beleevers. $\left(A 7^{\mathrm{v}}\right)$

Godly Puritans were taught to examine their hearts privately so that they would know if they were one of God's elect, and so destined to be saved at their death. To try to ascertain this, Venn read the Bible and noted down her ‘dayly Meditations’, and, curiously, kept these ‘in book fair written’, along with a 'Folio' of profitable ministry, also 'fairly transcribed'. Most revealingly, Knight wrote that Venn had gathered all the scriptures she could find 'for the strengthening of the faith of beleevers', which suggests that she wished to help other godly people to interpret and meditate on scripture and ministry using her 'fair' example. For Knight, Venn was 'exemplary in that holy art of the Improvement of the society of the Saints, by serious propounding of prepared questions' $\left(\mathrm{A}^{\mathrm{v}}\right)$, and also, contrary to what she wrote herself, 'able and ready to communicate richly unto others' (A7). ${ }^{3}$ The personal struggles she experienced were published, as Knight recognized, 'for our example, that we may tread in her steps, and be followers of her as she 
followed Christ' (A8). Weld hoped the publishing of Venn's experiences would be 'useful in these declining times to convince some Christians of their slackness and awaken others, and shew them how to make more heart-work by the example of one of the weak Sex' (A5). If a woman (deemed more sinful and more liable to be deceived by Satan) could live such a godly life, there was hope for all.

It is perhaps unsurprising that a published version of Venn's experiences came into the hands of wealthy gentlewoman, Anne Dunch: she and Venn had more in common than just their names. Both their fathers, John Venn and Richard Major, were involved in the rise of Oliver Cromwell to the position of Lord Protector. Venn was the only surviving daughter of Colonel John Venn, an active parliamentarian and regicide, whom she describes as the 'chief comfort of [her] natural life' $\left(\mathrm{C}^{\mathrm{v}}\right)^{\mathrm{v}}{ }^{4}$ His death on 28 June 1650 permeates Venn's narrative, as she felt God was punishing her for her sins. Her strength and recovery would surely have seemed relevant to Anne Dunch, who, by 1658, had seen the death of Oliver Cromwell (her sister's father-inlaw), the departure of her brother-in-law, Richard, to London, and the death of her fourth child, Anne. Dunch was related to Cromwells, both by the marriage of her sister to Richard, but also by her husband's uncle, William Dunch, who had married Cromwell's aunt, Mary. Cromwell's letters indicate that he perceived her father Richard Major as 'very wise and honest; and indeed to be valued', and praised 'the gentleman's plainness and free dealing' with him over the engagement of his son to Major's daughter, Dorothy. ${ }^{5}$ The couple were married on 1 May 1649 at Hursley, and lived with Major before and after Richard's Protectorate was deposed. Anne and John's children were all 
baptised at Hursley until after the birth of their son John in 1659, suggesting that they too lived, for the most part, in the company of Dorothy and her husband. By 25 April 1660, Richard Major was dead, sparking rumours of suicide because of the restoration of Charles II, and Anne and her family moved to Pusey, Berkshire (an estate owned by John’s father Samuel Dunch) where the unlawfulness of their next daughter Dorothy's baptism was recorded by the church courts on 10 September $1662 .{ }^{6}$ The ordinance was performed at the house by 'one Mr Lancaster, a minister of Hampshire', who had been ejected from his living under the 1662 Act of Uniformity, instead of the local parson. $^{7}$ John's father Samuel left bequests to several ejected Hampshire and Berkshire ministers in his will, including $\mathrm{Mr}$ Lancaster and his chaplain Samuel Blower. ${ }^{8}$ Anne Venn also left money to various ministers whom she had mentioned in her narrative, including Isaac Knight and the fifthmonarchist, John Rogers.

The signatures of Anne Dunch and her family hint not only at ownership, but at their affiliation to ideas that Venn's work expressed. Dunch, like Venn, seems to have been part of a family of nonconformists and both were profoundly affected by the rise of Cromwell and the establishing of the Protectorate. The Dunch family apparently responded to the publishing of Venn's experiences for the community of the godly, as an 'alarum to the Saints' in, what they perceived as, a 'licentious age' $\left(\mathrm{A} 6^{\mathrm{v}}\right)$.

\section{ENDNOTES}

${ }^{1}$ Anne Venn, $\underline{\text { A Wise Virgins Lamp Burning [...] Being the Experiences of }}$ Mrs. Anne Venn (London, 1658), Bb3. All subsequent quotations are taken 
from this edition and page numbers will follow in parentheses. There are five extant copies of Venn's published work which are held at the British Library, Dr Williams’s Library, the American Antiquarian Society, Harvard University, and the New York Public Library in America. Sadly, Venn's experiences have received very little critical attention despite their valuable insights into the gathering of London Presbyterian and separatist congregations. I have written briefly about these signatures in 'A Good Example to Women': The Biographer’s Presence in mid-Seventeenth-Century Women’s Conversion Narratives', The Glass, xxi (2009), 11-19.

${ }^{2}$ John and Anne Dunch had eight children altogether, six of whom were born by 1658 and all baptised at Hursley: Major (bap. 9 August 1651), Samuel (bap. 26 September 1652), Dulcabella (bap. 29 September 1654), Anne (bap. 22 June 1655 and died before March 1657), Edmund (bap. 3 September 1656), Anne (bap. 11 March 1657). The couple had a further child at Hursley: John (bap. 5 October 1659). Another child, Dorothy, was baptised on 1 May 1662 at Pusey, Berkshire, and another, William, whose baptism date is unknown. See HRO 39M69/PR3; PRO 11/328; Violet M. Howse, Pusey: A Parish Record (Faringdon, 1972), p. 48; Pete Annells, The Berkshire Dunches (Published by the author, 2006), p. 231. It isn't clear why Edmund's name did not appear on the list of signatures. Perhaps it is a sign that he had not yet heard the narrative read in the family, and so his name was not recorded.

${ }^{3}$ Venn wrote that, one evening, she composed a letter for 'a dear kinswoman of mine' who 'lay under some sad dispensation from the Lord' (E3), and later wrote a prayer request to the Fulham congregation on behalf of a male 
relation. Afterwards, she thought she would continue, 'not to do it onely in his behalf, but also in the behalf of other poor dark souls in relation to me' (I6). ${ }^{4}$ John Venn had three children with his first wife, Mary Wood: John (bap. 13 June 1621 and bur. 27 February 1623), Richard (bap. 17 October 1622 and bur. 13 April 1625), and Thomas (bap. 21 December 1624). With his second wife Margaret he had Anne (bap. 1 January 1627), John (bap. 15 December 1629), and Simon, Samuel, and another Simon, who lived no more than two years each. See The Registers of All Hallows, Bread Street, and of St John the Evangelist, Friday Street, London, ed. by W. B. Bannerman, vol. 43 (Harleian Society Registers, 1913); John Venn, Annals of a Clerical Family: Being some account of the family and descendants of William Venn, Vicar (London, 1904), p. 230.

5 Thomas Carlyle, The Letters and Speeches of Oliver Cromwell with Elucidations, (London, 1904), I, p. 396.

6 John Dunch died in November 1668, shortly after his father, and so only inherited this property for a short time. According to John's will, Anne had predeceased him by three years: PRO 11/328.

${ }^{7}$ Howse, Pusey: A Parish Record, p. 49.

${ }^{8}$ Samuel Dunch left bequests to ten ejected ministers including Mr Lancaster. These included his chaplain Samuel Blower and Vavasor Powell who had been imprisoned in Southsea Castle for five years. See PRO 11/328. Anne Venn left bequests to Isaac Knight and John Rogers of $£ 5$ each. The ministers she mentions in her narrative (Sidrach Simpson, Matthew Barker, Stephen 
Marshall, Thomas Archer, and Henry Jessey), all received twenty shillings, see PRO 11/243. 